\title{
The Categories of Jonathan Edwards' Natural Philosophy Applied to Organic Chemistry: An Integrative Example
}

\author{
Dana E. Johnson
}

check for updates

Citation: Johnson, Dana E.. 2021. The Categories of Jonathan Edwards Natural Philosophy Applied to Organic Chemistry: An Integrative Example. Religions 12: 151. https:// doi.org/10.3390/rel12030151

Academic Editors: Joel B. Green and John A. Bloom

Received: 16 December 2020

Accepted: 24 February 2021

Published: 26 February 2021

Publisher's Note: MDPI stays neutral with regard to jurisdictional claims in published maps and institutional affiliations.

Copyright: (C) 2021 by the author. Licensee MDPI, Basel, Switzerland. This article is an open access article distributed under the terms and conditions of the Creative Commons Attribution (CC BY) license (https:// creativecommons.org/licenses/by/ $4.0 /)$.
Department of Chemistry, Physics and Engineering, Biola University, La Mirada, CA 90639, USA;

dana.johnson@biola.edu

\begin{abstract}
In addition to Jonathan Edwards' extensive bibliography in philosophy and theology, there exists much writing devoted to natural philosophy where he makes reference to man's ability to recognize God's order, beauty, and goodness in Creation. The following demonstrates these categories specifically with regard to Edwards" "Spider" papers, then as they apply to the more modern field of organic chemistry. Jonathan Edwards laid an important foundation for how to view the world that continues to support a healthy scientific enterprise.
\end{abstract}

Keywords: Jonathan Edwards; natural philosophy; integration; organic chemistry

\section{Introduction}

Undoubtedly, there is little to directly connect Jonathan Edwards, theologian and author from the 18th century, to the class of chemistry reactions known as pericyclic reactions, whose underlying action was first clearly elucidated as recently as the 1960s. The bulk of Edwards' writing consists of theology and philosophy, and he is routinely omitted from lists of scientists from his century, though he could scarce be considered to be ignorant of the science developing around him. He lived after Robert Boyle and Isaac Newton and was a contemporary to Benjamin Franklin. Edwards was highly educated, and he cultivated work habits such that his biographer likened him to a "busy bee, collecting from every opening flower, and storing up a stock of knowledge, which was indeed sweet to him, as the honey and the honey-comb" (Hopkins 1765). Images of nature occur throughout his works, and his goal is to use those images to point the reader to a greater appreciation of the Author of the Book of Nature. He tends not to formulate arguments attempting to prove the existence of God. His aim is to give examples of how God is exemplified in His creation, and he writes concerning the categories of Order, Beauty, and Goodness.

Pericyclic reactions incorporate an entire branch of reactions within the discipline of organic chemistry. These are reactions that, until recently, were very difficult to explain. Ordinarily, chemists attempt to describe reactions as moving through a step-by-step process known as a mechanism. The pericyclic reactions occur without any such steps and became known as "no-mechanism" reactions (Carpenter 2015). The process of figuring out how to understand these reactions is fascinating, though only a brief accounting will be given here. The author intends to show how the pericyclic reactions can also be seen to exemplify the three categories of Jonathan Edwards' natural philosophy. Order was achieved from the chaos of the "no-mechanism" reactions. The explanation of product formation is a simple formulation of a complex set of reactions, the combination of which is typically described as beautiful. And there is a specific example of how the limitations of the pericyclic reactions protect man from DNA damage, an expression of God's goodness toward what He has made.

\section{Jonathan Edwards in Brief}

The pre-eminent American theologian Jonathan Edwards lived from 1703-1758. He was accomplished from a young age, graduating from Yale at 16 and obtaining his Master's 
degree at 19. By the time he was 23 , he had pastored two churches and was beginning a 23-year stretch preaching in Northampton, Massachusetts, a career that would make him one of the most recognized and respected theologians in America. A prolific writer, Edwards is known, in part, by the volumes of material he left behind including works on theology, philosophy and, to a much smaller degree, the natural sciences. His treatises on free will and original sin "secured his reputation in the academic world." (Sweeney 2009) Edwards also influenced the mission's movement through his biography of David Brainerd and his work at the Stockbridge Indian Mission (Sweeney 2009).

Despite his busy life teaching the Word of God, Edwards maintained a connection with the created world. It was common for him to ride his horse out into the countryside for walks in the evenings, noting the details of the world around him. Edwards spoke of the need for Christians to understand not only the Book of Scriptures that has been revealed by God, but also the Book of Nature that has been created for us. Both Books have a divine origin and speak of eternal things (Sweeney 2009). As a result, images of nature make up a beautiful and recurring motif throughout the writings of Jonathan Edwards.

\section{Jonathan Edwards and His Connection to Nature}

Jonathan Edwards always spoke of the strong connection between the earthly and the spiritual, as the former was created to give us an understanding of the latter. This is borne out by the fact that many of his writings on natural philosophy were written after his conversion. While he was writing his more theologically centered "Notes on Scripture" and "Notes on Revelation," he was also writing such essays as "Beauty of the World," "The Mind," and adding to his "Miscellanies," which contains many entries on nature (Anderson 1980).

His own "Personal Narrative" contains multiple examples of his love for the world around him as well as the spiritual pictures they represented. After a discussion of the beauty of Jesus, Edwards walked through his father's pasture and gloried in the cloudy sky. He seemed to have trouble putting into words his response to the scene around him. "[I]t was a sweet and gentle, and holy majesty; and also, a majestic meekness; and awful sweetness; a high, and great, and holy gentleness" (Edwards 1995d). Later, he described the soul of a true Christian as a "little white flower" in a field, peacefully drinking in the rays of the sun's glory, gently spreading its fragrance throughout the valley around it. After a prolonged illness in 1725, Edwards compared the sunlight coming through his windows in the morning to the "sweet light of God's glory" (Edwards 1995d). He spoke many times of reflection and communion with God taking place outside, both in solitude or in conversation with a close friend.

Edwards felt the connection between the created world and the revealed Word was more than simply visceral or poetic. He spent much time codifying the many ways that nature exemplified specific spiritual truths. Just as he recorded the many examples of Scripture that are "types" of the Messiah or the verses that contained a deeper correlation to a spiritual truth, Jonathan Edwards wrote about the examples in nature that spoke of a larger message from God. The idea that nature could contain higher truths was founded, in part, on his study of Scripture, which uses examples from nature to teach. Edwards used as one example, 1 Corinthians 15:36 (NIV), "How foolish! What you sow does not come to life unless it dies." This verse is used in a discussion of the resurrection, using a picture from agriculture to illustrate the idea that life comes only after death. Edwards also noted the multiple uses of "terrors and billows of the sea" as pictures of God's wrath. Some of his examples had stronger connections between the sacred and the earthly than others. He compared the silkworm to Christ, as both provide "glorious clothing" upon their death. He also used the bowels full of dung as a way to communicate the natural filthiness of man's heart (Edwards 1995b). Yet, his writings on these spiritual connections, when taken together, show a mind that was always fixed on seeing God.

What must be remembered is that Edwards sought to clearly show God working throughout His creation. In some ways, he was reacting to a prevailing mechanistic 
interpretation of nature, which meant to reduce all aspects of nature to matter and motion. Rather than a God who is absent from His created world, Edwards was convinced that the world constantly reveals both God's glory and presence. As a result, he has been characterized as a theologian and scientist who sought to "re-enchant" the world around him as a response to the philosophy that reduced the world to nothing more than matter acting on other matter (Zakai 2010).

In the process of this "re-enchantment," Edwards codified a series of three interconnected categories as he approached the world around him. Rather than focusing on his extensive typologies and the specific spiritual correlations made there, I would like to focus on these categories and how they can be connected to research within the sciences, with a specific example in organic chemistry.

\subsection{Order}

Edwards' typology may be the major source of his category of order within the created realm. "[T]he things of the world are ordered [and] designed to shadow forth spiritual things" (Edwards 1995b). Because he saw this connection between the earthly and the spiritual, he expected to see order in the world around him. He recognized that order in the world had already been found; he was not claiming to originate this idea. However, in his estimation, a connection to God informed what that order meant. He used the term "religion" to communicate both connection to and glorification of God's works. And without religion, "[A]ll those vast bodies we see ordered ... according to such laws of gravity and motion, would be ... good for nothing and to no purpose at all" (Edwards 1995c).

\subsection{Beauty}

In his short essay "Beauty of the World," Jonathan Edwards drew on his typological understanding that physical things are shadows of higher spiritual things. Even though spiritual things are "infinitely the greatest," the physical shadow must still possess a good portion of the beauty of the thing it represents. He also described a continuum of beauty that can be found. One end of the spectrum involves easier to discern examples of beauty in nature, as they are "palpable and explicable." One thinks of the beauty of a sunset or the view from a mountain. The other end of the spectrum included examples that are "hidden and secret," which Edwards describes as "by far the greatest" (Edwards 1995a). This would include ideas of systems regulation as we will see below.

\subsection{Goodness}

Edwards' category of goodness in creation may not be as clearly understood from his writings as his others, though it is still based on his understanding that God is revealed as the world is discerned. As the mysteries of nature are searched and found out, we "find out the proportion of God's acting" (Edwards 1995e). Edwards went on to say that our end as intelligent beings is "to behold and admire the doings of God, and magnify him for them, and to contemplate his glories in them" (Edwards 1995c). Wallace Anderson, the editor of a volume of Edwards' scientific and philosophical works, noted that Edwards "celebrated" the succession of events in the world around him as they unfold "according to an original plan of providence" (Anderson 1980). From Edwards' Personal Narrative, we see he spent a good deal of time contemplating "the lovely way of salvation, by free grace in [Christ]," after his conversion (Edwards 1995d). Just as God was good to offer salvation to man, he looked for other ways of seeing God's providence to man in nature. This idea extended to include providence to other created beings, as we will see as we look at his "Spider" papers.

\section{The "Spider" Papers}

"Of Insects" and "The 'Spider' Letter," both of which were written in 1723, give the clearest picture of his experimental methods and are great examples of his writing in the 
sciences. (The "Letter" was actually submitted to the Royal Society of London, though it is remembered mostly due to anthologies of Edwards' work.) First, he made note of a particular question that needed answering, and he limited his inquiry to one specific species of spider, recognizing that different species may give different answers. Simply stated, he wished to understand the mode by which these spiders moved through the air from tree to tree (Edwards 1980). Though he was not the first to write about these questions, he is, undoubtedly, the most famous in this time period to do so. He was part of a larger dialogue that included names such as Lister and van Leeuwenhoek, and his writing on the subject of flying spiders is a fine example not only of his observational skills but of his ability to integrate the character of God with what he saw around him (Wilson 1971).

As observation is the key to gaining the information he needed, Edwards found multiple ways to observe the spiders at work. On clear, calm days, he watched the spiders from behind an object sufficiently large to shield his eyes from the sun, while still allowing him room to observe. From that vantage point, he clearly saw "multitudes of little shining webs and glistening strings of a great length," which seemed to carry these spiders through the air (Edwards 1980). He gained a closer look in two ways. First, he obtained a spider on the end of a stick, which he could bring close to his face. By shaking the stick, he incited the spider to let out a strand of a web to "escape." Second, wishing to get a better look at the fine web of the spider, he held the stick with the spider in front of a dark door and shook the stick again. The contrasting light web and dark background gave him the visibility to clearly see how the spider escaped through the air (Edwards 1980). By repeating these experiments multiple times, he was able to determine a pattern of action. Both spider papers contain illustrations, showing how spiders dropped down from the end of the stick and escaped through the air using their webs.

In the end, he gave a clear method the spider used to both attach a web between two distant points and seem to fly through the air from one tree to another. The spider lets out its web, which behaves as though it is lighter than air and floats even on calm days. Assuming the web does not attach to another tree, it will eventually be long enough to bear the spider into the air, much like a sail. Edwards drew on his understanding of buoyancy to try to explain this effect. He spoke of how the buoyant force on the web must be great enough to counteract the gravity (his word for "weight") of the spider, which is why the web had to have great length before the spider was airborne. He compared the effect to a man who is held afloat by a piece of wood (Edwards 1995f). Just as the wood must be of sufficient size to keep a man afloat, so must the web be long enough to bear a spider aloft. Edwards' commentary on the observation of flying spiders was part of a larger discussion of the natural philosophers of his time. The works referenced here were his contribution to the discussion attempting to bring the idea of a flying spider within the ordered picture of how spiders behave and move (Wilson 1971).

Additionally, Edwards noted the beauty of the spider's movement in two distinct ways. At first, he observed beauty on the more explicit end of his beauty continuum mentioned above. Simply observing the "glistening" strands of the spider webs and the motion of the spiders through the air was "very pretty and pleasing" to him, and this observation served as an impetus for trying to understand this aspect of nature (Edwards 1980). The second observation of beauty is closer to the other, more hidden end of this beauty continuum. Edwards noted that the motion of the spiders through the air resulted in the eventual demise of a multitude of spiders as they flew into the sea. Edwards recognized that spiders are destroyed through many means, and their fatal flight into the waves was one of the ways to regulate the population. This was a small part of the complicated workings of God in the interdependence of different species in nature. Finally, Edwards recognized even the goodness of God through this process. This process of flying spiders not only gives them a way to escape dangerous situations or to move large distances quickly, but also provides a way of travel that provides both "pleasure and recreation," even to the most "despicable" of creatures. He referred to this as an example of God's "exuberant goodness" (Edwards 1980). 


\section{Edwards' Categories in Organic Chemistry}

Now, let us look at how these three characteristics of order, beauty, and goodness can be seen in one of the major breakthroughs in organic chemistry. Even though the researchers involved did not have the same theological commitments as Jonathan Edwards, one can still clearly see these characteristics within their work. We will look at the application of what became known as the Woodward-Hoffmann Rules to a class of organic reactions and how they demonstrate a previously unseen order, a simple and beautiful solution to a confusing set of reactions and a clear picture of God's goodness in creation.

Robert Woodward and Roald Hoffmann published a series of papers on a class of reactions called pericyclic reactions in the early 1960s. Pericyclic reactions are one-step reactions in which the electrons in one or more starting molecules are rearranged to form product, without following a typical multi-step mechanism involving intermediates. As this "no mechanism" type of reaction comprises one of the three major classes of organic reactions, the work of these two researchers was crucial to a solid foundational picture of organic chemistry.

There are three main types of pericyclic reactions: electrocyclic reactions, cycloaddition reactions, and sigmatropic reactions. Electrocyclic reactions are intramolecular reactions where one starting molecule either forms a closed ring or, working in reverse, a closed ring opens. The second type of reaction, the cycloaddition reaction, forms a closed loop from two separate molecules, or the reaction can, again, reverse to produce two molecules from one starting cyclic molecule. Sigmatropic reactions, the third type, are another intramolecular reaction where either a single hydrogen atom or a larger portion of the molecule is transferred to another part of the molecule. These may seem like very disparate sounding reactions, yet they have some basic structural motifs in common. First, every molecule that is eligible for a pericyclic reaction must have double bonds, which means the electrons are in very specific positions within the molecule. Second, if the starting molecule has more than one double bond, the double bonds must be conjugated, which simply means that the chain of carbons within the molecule must alternate between double and single bonds.

Woodward, a Nobel Laureate for his contributions to organic chemistry before his work with Hoffmann, began to see a pattern throughout the chemical literature of these mysterious "no-mechanism" reactions. Woodward brought in Hoffmann, a theoretical chemist who would later win the Nobel Prize in 1981 for this work, to collaborate in hopes of understanding these pericyclic reactions (Seeman 2015). They only require a single step to form product, and the reactions appear to involve only a rearrangement of the electrons within the starting material. Even though they had a good theoretical understanding of these pericyclic reactions, they were confronted with a growing literature of reactions that seemed to operate at random, with no predictive structure in place to adequately explain how these reactions worked (Wilkinson 2003). One possible example to illustrate this could be an electrocyclic reaction with the hydrocarbon 2,4-hexadiene, seen in Figure 1.

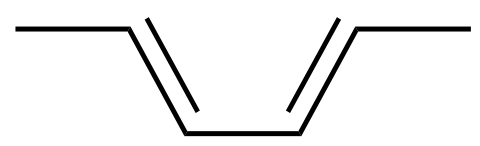

Figure 1. 2,4-Hexadiene.

Some further explanation of Figures 1 and 2 is needed for those with little background before the reactions themselves can be explained. The actual name of the starting molecule, 2,4-hexadiene, is simply telling us that there are six carbons ('hexa') and two ('di') double bonds. Other information has been deliberately omitted for clarity's sake. The drawings in both figures are shown in skeletal formation, which means only the bonds between the carbons are drawn, and all bonds to hydrogens are omitted, again, for clarity. Therefore, a single straight line is connecting two carbons and signifies a single bond. Two parallel lines signify a double bond. Notice 2,4-hexadiene alternates double and single bonds, which is 
one of the criteria for these reactions. Also, the starting molecule is flat, and the plane of the molecule is drawn to be parallel to the plane of the page. The products in Figure 2 use both solid and dashed wedges, which indicate bonds that are no longer planar with the page. The solid wedge indicates a bond that is coming out of the plane of the page toward the observer, and the dashed wedge indicates a bond that is going into the plane of the page away from the observer.

\section{2,4-Hexadiene}

Figure 2. 2,4-hexadiene and the different products obtained via a heat- or light-induced process.

There are several things to notice in the reactions shown above. The starting molecule, 2,4-hexadiene, can give several different products, even though the type of reaction is the same (an electrocyclic reaction) in all cases. If the reaction is run under conditions where only the energy from heat is applied, two products form that are mirror images of each other. (The arrow indicates movement from starting material to product.) If a greater amount of energy from ultraviolet (UV) light is added to the reaction, only one product forms that is different from the two obtained via the heat process. Further complicating this picture is the fact that this same set of products (all three of them) can be obtained from an isomer of 2,4-hexadiene, where one of the bonds points in a different direction. Figure 3 shows how the three products are obtained from the two different starting molecules.

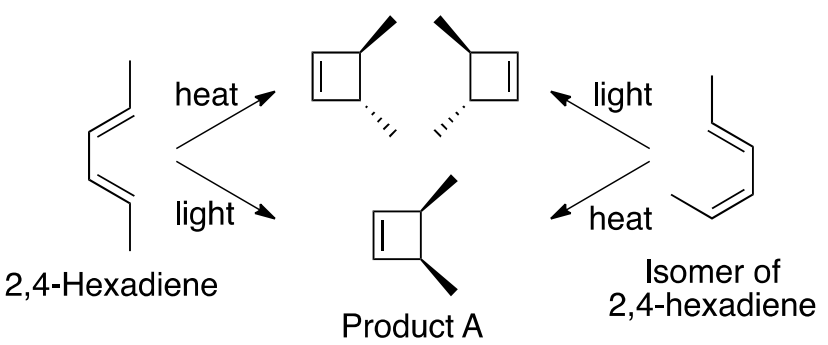

Figure 3. The set of products obtained by both 2,4-hexadiene and its isomer via heat- and lightinduced processes.

Let us think how the above reactions illustrate the confusion that was prevalent in the literature surrounding these types of reactions. Two different starting materials could give identical products, yet the process to obtain the same products was different depending on the starting material. Notice that both 2,4-hexadiene and the isomeric starting material could give Product A. However, 2,4-hexadiene needed UV light before forming Product A, while the other starting material needed only heat applied. And the reaction conditions to form the other products are similarly flipped. One starting material needs heat, while the other needs light. There are countless other examples not only of electrocyclic reactions, like the above, but also of cycloaddition and sigmatropic reactions where the constraints on the reactions did not seem to follow any discernible pattern. Additionally, there were examples of reactions that would ONLY work if heat was applied or ONLY work if UV light was applied. One could codify these reactions, but explaining the reasons behind them in order to open doors for predicting products had eluded researchers until Woodward and Hoffmann started to work on this problem (Wilkinson 2003). 
One of the keys to determining the solution involved an understanding of the positioning of the electrons within the starting molecules. Electrons, which form the various bonds within a molecule, are constrained to specific locations within the molecule called orbitals. As previously stated, the starting molecules in pericyclic reactions all have double bonds, which are formed from orbitals that have a dumbbell-like shape, seen in Figure 4. These orbitals are also typically shown with one shaded lobe and one unshaded lobe. This is a simple picture of the complicated mathematics that is involved in describing an orbital. The shading helps to differentiate one side of the orbital from the other as only the parts of the orbitals with the same shading can interact and form bonds. As we shall see, the two different orbital ends became an important element in determining how these reactions were ordered.

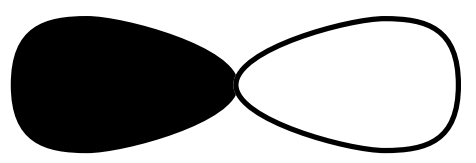

Figure 4. A representation of an orbital, which houses the electrons in a double bond.

Hoffmann, as the theoretical chemist, was able to work through the complicated mathematics involved in describing the electron locations within the various orbitals in these molecules and began to notice a pattern (Seeman 2015). The reactions were always dependent on the phasing of the orbitals that were on the ends of the series of double bonds. When these terminal orbitals would move to form bonds in the products, they would need to rotate in such a way as to only align similarly shaded lobes. (Imagine the orbital is able to rotate like a propeller.) Only two lobes with the same shading could form a new bond (Woodward and Hoffmann 1971). This became a key to understanding the constraints that were seen in these reactions.

Figure 5 illustrates the two possible configurations of the terminal orbitals in any starting molecule for any pericyclic reaction. Since we are only focused on the two orbitals on the end, the rest of the molecule has been reduced to the curved line. Structure A shows a molecule where the terminal orbitals are oriented in the same direction-both shaded lobes are pointing up. Structure B shows the terminal orbitals that point in opposite directions. These two orbitals will need to rotate in order to overlap to form the new bond in the product, yet only similarly shaded lobes can overlap. The product with the shaded lobes overlapping is Structure C. (One could also draw a product with the unshaded lobes overlapping, and the process is the same.) Notice how the terminal orbitals in A and B must rotate to form C. In Structure A, the orbital on the left must rotate clockwise, while the orbital on the right must rotate counterclockwise to place the shaded lobes in the correct position. In Structure B, both orbitals must rotate clockwise in order to be in the correct position. This difference in rotation may seem trivial, yet it is enough to yield completely different products. Woodward and Hoffmann were able to clearly demonstrate how the various products of pericyclic reactions were dependent on whether the starting material resembled Structure A or B in Figure 5 (Woodward and Hoffmann 1971). They uncovered a previously unseen order that unified all the pericyclic reactions.

Another indication of the order that was being uncovered was the fact that the specific product formed via a pericyclic reaction was based solely on the number of double bonds and the reaction conditions (Woodward and Hoffmann 1965). Many of the molecules that served as starting materials for many of the pericyclic reactions were quite complicated in structure, yet the only detail of the structure that was important for the reaction to move forward was the number of double bonds that alternated with single bonds in the molecule. The only detail about the reaction conditions that was needed to predict which products would form was whether heat or light was the energy source. Pericyclic reactions were now predictable and no longer a mystery, as the large number of possible factors that controlled these reactions was reduced to two easily definable characteristics. Woodward and Hoffmann could be said to have authored a simple, beautiful theory that explained 
observations, allowed for predictable results and placed an entire branch of synthetic organic chemistry on a solid, theoretical foundation (Wilkinson 2003).

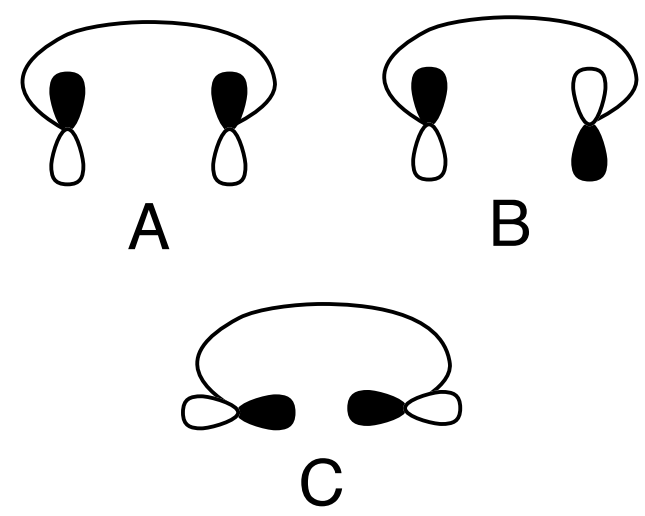

Figure 5. Three representations of the orbitals on the terminal ends of simplified molecules with double bonds. All other bonds and orbitals have been reduced to the curved line. $(\mathbf{A}, \mathbf{B})$ show the two possible orientations of the terminal orbitals, and (C) shows a correct overlapping of the orbitals to form a bond.

An example of God's goodness toward mankind may be found in one specific application of pericyclic reactions. The Woodward-Hoffmann Rules not only give a predictive framework for determining the product of a given reaction, but they also give constraints to reactions, explaining why certain reactions cannot move forward under certain conditions. The discussion so far has focused on electrocyclic reactions, though there are also cycloaddition and sigmatropic reactions under the umbrella of pericyclic reactions as well. These two types of reactions are also dependent on the same starting conditions as electrocyclic reactions, though the finer details are slightly different. One specific cycloaddition reaction is important to our daily lives as it involves our DNA, located within every cell in our body. A cycloaddition reaction involves two or more molecules reacting to form one product, and this is possible between two adjacent thymines within the genetic code of our DNA, forming a thymine dimer. (Thymine is one of the four nucleotide bases that make up our genetic code.) Figure 6 shows the possible reaction that can occur when two thymines are right next to each other within a DNA strand.<smiles>Cc1c[nH]c(=O)[nH]c1=O</smiles><smiles>Cc1c[nH]c(=O)[nH]c1=O</smiles><smiles>C[C@]12C(=O)NC(=O)NC1C1NC(=O)NC12</smiles>

Figure 6. Two adjacent thymine residues forming a thymine dimer via a cycloaddition reaction.

This reaction is noteworthy as the resulting thymine dimer is carcinogenic. The dimer interferes with the processing of DNA, which leads to mutations and eventually cancer ( Setlow 1966). Our cells have been designed to handle these dimers in a limited capacity by the inclusion of an enzyme called DNA photolyase, which reverses the cycloaddition reaction, re-forming two separate thymines. The goodness of God is seen in that this damaging reaction, according to the Woodward-Hoffmann Rules, can only occur under conditions where UV light has been applied. This reaction is impossible if only heat is used, which is more important than it sounds. Many pericyclic reactions can proceed with the amount of heat found at room temperature. Our body heat would be high enough to allow reactions to proceed. However, the reaction that produces the thymine dimer will not proceed without the energy from UV radiation. The ozone layer around the planet and a good sunblock both decrease the amount of UV light that reaches our cells. And our cells, generally, can handle the relatively few dimers that form through UV exposure via the 
work of DNA photolyase. If this reaction occurred with just our body heat, our cells may be overrun with thymine dimers, leading to an incredible increase in cancer. However, the laws that govern these reactions make this thermal reaction completely impossible.

\section{Implications of Jonathan Edwards for the Sciences}

By examining Jonathan Edwards' view of nature and how he attempted to understand the world around him, we can see how he carried his categories of order, beauty, and goodness into his investigations. These three categories were foundational for his view of nature as they are rooted in his understanding of who God is and how He reveals Himself. Even in the more modern example of pericyclic reactions, we can see the three categories appearing. Woodward and Hoffmann searched for and found the deeply hidden order that governed an entire class of reactions. Their work resulted in a powerful set of rules that beautifully showed the boundaries and limitations of these reactions and that gave the ability to predict the products of any pericyclic reaction. God's goodness can then be seen as we examine the implications of the Woodward-Hoffmann Rules for our DNA. We can see a divine barrier of protection around our cells' ability to replicate themselves, an action essential for our survival.

We must be clear what effect Edwards' views have on the scientific endeavor. My contention is not that Edwards' three criteria will bring about a new era of research or that they have the ability to drastically change how one goes about science. However, these three criteria can have the effect of placing the data we receive from experimentation within a proper framework that connects to a Christian worldview. George Marsden speaks of a Gestalt shift to explain the change that can occur while looking upon a set of data from a different set of foundational assumptions (Marsden 1984). Even though the data points may be unchanged, it is the different set of assumptions that change how we view the information.

Currently, a mechanistic and naturalistic worldview dominates the scientific establishment. Scientists within this framework search for clearly understood laws that govern the world around us, even though they may not be able to give a reason why these ordered laws should exist in the first place. Richard Lewontin, a prominent evolutionary biologist, acknowledges that order does not make sense within the framework of materialism, but it should be accepted anyway (Lewontin 1997). Laws that are simple and elegant are highly valued over the complicated and arcane. Physicist Brian Greene speaks of the way research decisions are made in search of desired aesthetic, a "deep inner elegance" within the theories, and the word "beautiful" is invoked when speaking of simple theories explaining the richly diverse world around us (Greene 1999). Though why one would expect beauty in the simplicity is not clearly defined (Schaefer 2003). When a resulting law thoroughly explains a phenomenon that seems to work only for our good rather than our detriment, it is seen as luck or happenstance.

Within the Christian worldview of Jonathan Edwards, the categories of order, beauty, and goodness naturally flow out of the character of God seen in His creation. We can approach a research question expecting to find an ordered explanation that underlies any phenomenon, as God has created the world around us as a foreshadowing of unseen spiritual things. We would expect to see beauty in the world around us, if it, indeed, is a shadow of infinitely greater spiritual things. As it is God Who is revealed through nature, we should also expect to see examples of His goodness throughout. And even though one can acknowledge the effects of the fall on the created order, the expectation for order, beauty, and goodness is not completely negated.

From either a materialistic or Christian worldview of nature, the same data may be obtained to explain some set of observations. However, it is the Christian worldview that gives a profound underlying reason for that data. Jonathan Edwards clearly understood the implications of God's act of creation for how we should understand what is around us. Not only can we expect to find examples of order, beauty and goodness, but also the truth that we find as a result will cause us to rejoice as if we have seen a shadow of God Himself. 
Funding: This research received no external funding.

Conflicts of Interest: The author declares no conflict of interest.

\section{References}

Anderson, Wallace E. 1980. Editor's Introduction. In Works of Jonathan Edwards. Vol.6-Scientific and Philosophical Writings. New Haven: Yale University Press, pp. 37, 49.

Carpenter, Barry K. 2015. Beauty in Simplicity: Celebrating 50 Years of the Woodward-Hoffmann Rules. Journal of Organic Chemistry 80: 11630. [CrossRef] [PubMed]

Edwards, Jonathan. 1980. Of Insects. In Works of Jonathan Edwards Vol. 6-Scientific and Philosophical Writings. Edited by Wallace E. Anderson. New Haven: Yale University Press, pp. 154-57.

Edwards, Jonathan. 1995a. Beauty of the World. In A Jonathan Edwards Reader. Edited by John E. Smith, Harry S. Stout and Kenneth P. Minkema. New Haven: Yale University Press, pp. 14-15.

Edwards, Jonathan. 1995b. Images of Divine Things. In A Jonathan Edwards Reader. Edited by John E. Smith, Harry S. Stout and Kenneth P. Minkema. New Haven: Yale University Press, pp. 16-19.

Edwards, Jonathan. 1995c. Miscellanies. In A Jonathan Edwards Reader. Edited by John E. Smith, Harry S. Stout and Kenneth P. Minkema. New Haven: Yale University Press, p. 36.

Edwards, Jonathan. 1995d. Personal Narrative. In A Jonathan Edwards Reader. Edited by John E. Smith, Harry S. Stout and Kenneth P. Minkema. New Haven: Yale University Press, pp. 284-90.

Edwards, Jonathan. 1995e. The Mind. In A Jonathan Edwards Reader. Edited by John E. Smith, Harry S. Stout and Kenneth P. Minkema. New Haven: Yale University Press, p. 29.

Edwards, Jonathan. 1995f. The 'Spider' Letter. In A Jonathan Edwards Reader. Edited by John E. Smith, Harry S. Stout and Kenneth P. Minkema. New Haven: Yale University Press, p. 4.

Greene, Brian. 1999. The Elegant Universe. New York: Vintage Books, p. $166 \mathrm{ff}$.

Hopkins, Samuel. 1765. The Life and Character of the Late Reverend Mr. Jonathan Edwards. Boston: S. Kneeland, p. 41.

Lewontin, Richard. 1997. Billions and Billions of Demons. In New York Review of Books. New York: Rea S. Hederman.

Marsden, George. 1984. Common Sense and the Spiritual Vision of History. In History and Historical Understanding. Edited by C. T. McIntire and Ronald Wells. Grand Rapids: William B. Eerdmans Publishing, pp. 61-62.

Schaefer, Henry F., III. 2003. Science and Christianity: Conflict or Coherence? Apollo: The Apollos Trust.

Seeman, Jeffrey I. 2015. Woodward-Hoffman's Stereochemistry of Electrocylic Reactions: From Day 1 to the JACS Receipt Date (May 5, 1964-to November 30, 1964). Journal of Organic Chemistry 80: 11632-71. [CrossRef] [PubMed]

Setlow, Richard B. 1966. Cyclobutane-Type Pyrimidine Dimers in Polynucleotides. Science 153: 379-80. [CrossRef] [PubMed]

Sweeney, Douglas A. 2009. Jonathan Edwards and the Ministry of the Word. Downers Grove: InterVarsity Press, pp. $42-182$.

Wilkinson, Sophie. 2003. Symmetry Rules! Chemical E Engineering News 81: 59.

Wilson, David S. 1971. The Flying Spider. Journal of the History of Ideas 32: 447-58. [CrossRef]

Woodward, Robert B., and Roald Hoffmann. 1965. Stereochemistry of Electrocyclic Reactions. Journal of the American Chemical Society 87: 395-97. [CrossRef]

Woodward, Robert B., and Roald Hoffmann. 1971. The Conservation of Orbital Symmetry. Weinheim: Verlag Chemie, pp. 3-116.

Zakai, Avihu. 2010. Jonathan Edwards' Philosophy of Nature: The Re-Enchantment of the World in the Age of Scientific Reasoning. London: Continuum International Publishing, pp. 234-43. 